\title{
Degradation of phytoplankton detritus by bacteria: estimation of bacterial consumption and respiration in an oxygen chamber
}

\author{
Susanne Bauerfeind \\ Institut für Meereskunde an der Universität Kiel, Düsternbrooker Weg 20, D-2300 Kiel 1, \\ Federal Republic of Germany
}

\begin{abstract}
Consumption of the dissolved compounds of phytoplankton detritus (dinoflagellates, diatoms) by natural bacterial populations of the Kiel Bight area was studied. Experiments simulated the situation during degradation of a phytoplankton bloom in the water column, when high concentrations of dissolved organic material are released. The experiments were conducted in a chamber which allowed continuous monitoring of the oxygen concentration. Subsamples were taken at short time intervals for determination of bacterial number and biomass, and of dissolved organic compounds (concentration and molecular weight). These experiments allowed evaluation of the bacterial biomass increase in the absence of predators, without addition of a labelled substrate. The bacteria consumed dissolved substances very rapidly, resulting in an increase of bacterial biomass of more than $500 \mu \mathrm{g}$ $\mathrm{Cl}^{-1} \mathrm{~d}^{-1}$. It was shown by oxygen measurements, that up to $80 \%$ of the bacterial gross uptake was respired. This indicates the importance of bacteria as remineralizing organisms in the water column.
\end{abstract}

\section{INTRODUCTION}

Bacteria have the ability to use trace concentrations of dissolved organic compounds by either incorporating them into their biomass, which is then passed up the food chain to microheterotrophic organisms (e. g. flagellates, ciliates), or by remineralizing them, thereby making the inorganic nutrients again available for primary producers. Especially the evaluation of the bacterial activity is in discussion today. Since the introduction of the method by Wright and Hobbie (1966) many authors have estimated the turnover of single, low-molecular weight compounds labelled with radioactive carbon or tritium (e.g. glucose, amino acid mixture, acetate) added to the water sample in nearly natural concentrations. For the Kiel Fjord and Kiel Bight area numerous data have been collected by Gocke (1977).

The following problems exist with these uptake measurements:

(1) There are discrepancies between ${ }^{14} \mathrm{C}$ uptake measurements and oxygen consumption methods. Sepers et al. (1982) have found that ${ }^{14} \mathrm{C}$ uptake measurements lead to serious underestimation of bacterial activity, when compared to carbon mineralization as calculated from oxygen consumption measurements.
(2) The single substrates used for the experiments might be taken up in a manner other than naturally occurring organic solutes. Therefore several authors used the exudates of healthy, ${ }^{14} \mathrm{C}$ labelled phytoplankton cells as a complex and more natural substrate mixture for their uptake measurements. Results from these uptake measurements for the Kiel Fjord (Wolter, 1982) and the Central Baltic Sea (Larsson and Hagström, 1982) indicate that up to $15 \%$ of the newly fixed phytoplankton carbon is converted into bacterial biomass.

(3) For all ${ }^{14} \mathrm{C}$ uptake measurements the question remains as to whether ${ }^{14} \mathrm{C}$ labelled compounds are taken up in the same manner as the ${ }^{12} \mathrm{C}$ substances already in the water sample.

To avoid these problems it would be easiest to follow the bacteria-phytoplankton interrelation by measuring the changes in concentrations of the parameters involved in short time intervals. This way, one could avoid totally the addition of a labelled substrate. Attempts in this direction have been made by Johnson et al. (1981), who tried to follow the changes of $\mathrm{CO}_{2}$ and $\mathrm{O}_{2}$ concentrations in situ. In most cases, however, the changes in concentrations are too small to follow with the methods available, unless a substrate is added. Degradation experiments have been carried 


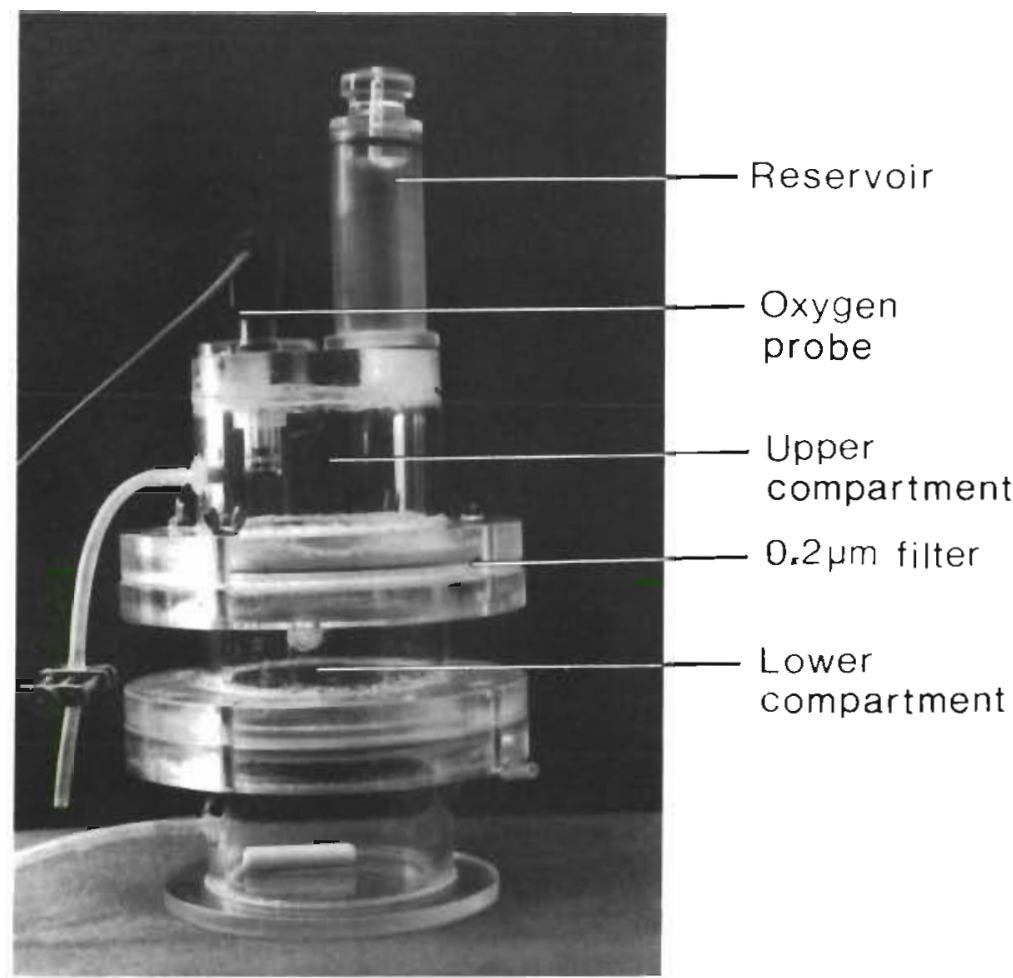

Fig. 1. Oxygen chamber

out in this way by Newell et al. (1981), who followed the degradation of phytoplankton by microheterotrophic organisms.

In the Baltic Sea high concentrations of dissolved organic material are sometimes available. Especially during summer and fall, the phytoplankton bloom does not sediment totally to the bottom. During these events a high percentage of the phytoplankton biomass is released due to 'sloppy feeding' by zooplankton and lysis of cells and is thus made available to the bacterial population. In the experiments described here, bloomforming phytoplankters (diatoms, dinoflagellates) were broken-up and added as a natural substrate to a water sample containing a bacterial population. The experiments were conducted in a container, which allowed continuous monitoring of the oxygen concentration. For determination of bacterial numbers and biomass, as well as dissolved organic substances, subsamples were taken at short time intervals. Therefore these experiments allowed calculations of the bacterial production and remineralization without the addition of labelled substances.

\section{MATERIAL AND METHODS}

Set-up of experiments. All experiments were conducted in the dark in a constant temperature room at in situ temperature. A $750 \mathrm{ml}$ plexiglass container was used for incubation of the samples (Fig. 1); the con- tainer was separated into 2 compartments by a sterile Unipore filter (pore size $0.2 \mu \mathrm{m}$, diameter $10 \mathrm{~cm}$, Bio Rad). A similar set-up was described by Wolter (1980). Prior to an experiment, the container and the tubing were submerged in a disinfecting detergent for at least $24 \mathrm{~h}$ to allow thorough cleaning. Thereafter, the vessel was rinsed with sterile deionized water and dried. Then the lower compartment was filled with the oxygen-saturated water sample, which had already been filtered through a $3 \mu \mathrm{m}$ filter to exclude predators and other particles. This precaution was necessary, to obtain realistic figures of the bacterial production in the absence of predators. For the same reason all experiments were run during winter (water temperature less then $10^{\circ} \mathrm{C}$ ) when the population of predators are not very dense (Gast, 1983), and then for only 22 to $66 \mathrm{~h}$. In this time, no large populations of ciliates or flagellates develop. According to Newell et al. (1981) there is a lag phase of $4 \mathrm{~d}$ for the microheterotrophic population to develop after the maximal bacterial number has been reached.

In order to fill the upper compartment the water sample was gently pressed with a sterile syringe, connected to the lower compartment through the membrane filter into the upper compartment. With this filtration a separation of bacteria and particulate organic matter from the dissolved compounds was accomplished. Even distribution of dissolved compounds across the membrane was checked in an advance experiment with acridine orange. In fewer than 
30 min after addition to the lower compartment the dye was distributed evenly in the whole vessel. In order to keep the material homogeneous a magnetic stirrer was used.

Oxygen measurements. An oxygen probe (Eschweiler and Co., Kiel) connected to a recorder was inserted airtight into the upper compartment. This allowed the continuous measurement of the oxygen concentration without bacterial contamination of the membrane of the probe, since the bacteria were concentrated in the lower compartment. A reservoir (Fig. 1) allowed subsampling from both compartments without air-bubble formation, which would have changed the oxygen measurements. Following temperature adaptation and stabilization of the oxygen probe, the probe was calibrated using the Winkler method (Grasshoff, 1976).

Preparation of phytoplankton debris. Altogether 4 experiments were conducted. For the first 2, phytoplankton were caught in the Kiel Bight in October 1981 with a $20 \mu \mathrm{m}$ mesh net. Until the start of the experiment the material was stored at $-20^{\circ} \mathrm{C}$. It was dominated by Ceratium species. These dinoflagellates often form blooms in late fall in the Kiel Bight (Smetacek, 1978). The third experiment was conducted with Peridinium cells from Lake Kinneret (Israel). The freeze-dried material was rediluted in tap water $\left(10 \mathrm{mg} \mathrm{ml}^{-1}\right)$ and then treated like the Ceratium cells. The cells were broken up by freezing and thawing the materials several times, until under the microscope only fragments of cells were visible. The phytoplankton material was heated to $60^{\circ} \mathrm{C}$ for 3 min shortly before the experiment in order to destroy the bacteria attached to the algal cells and to induce further lysis of the phytoplankton cells. One ml of the well mixed phytoplankton material (phytoplankton debris plus soluble substance) prepared in this way was added to the lower compartment after calibration of the oxygen probe. At the start of the experiments the amount of easy degradable substances (sugars and amino acids) was deternined.

The last experiment was carried out somewhat differently. Water from a $1 \mathrm{~m}^{3}$ enclosure experiment was taken and the experiment was run under natural light conditions and with high nutrient concentrations in order to stimulate a phytoplankton-bloom. During the exponential growth phase of the phytoplankton (Thalassiosira sp. and Skeletonoma costatum), water from the enclosure was transferred into the oxygen chamber. The experiment was run for $66 \mathrm{~h}$, because the concentrations of the organic material were much lower than in the other 3 experiments. In this experiment the phytoplankton cells were not destroyed prior to the experiment. The 3 other experiments were run 22 to $24 \mathrm{~h}$ until the oxygen concentration was lower than $2 \mathrm{mg} \mathrm{l}^{-1}$.

Bacterial parameters. Outlets in both compartments allowed subsampling at varying time intervals. Samples for the determination of bacterial numbers and biomass were taken from the lower compartment. These parameters were determined in the upper compartment, both at the beginning and at the end of the experiment, to check for contaminations, but the increase was negligible. Total bacterial numbers and biomass were determined from formalin-fixed samples ( $2 \%$ final concentration) after staining with acridine orange with an epifluorescence microscope according to the method of Zimmermann et al. (1978). The bacteria were grouped into size classes and their volume
Fig. 2. Concentration of dissolved free monosaccharides (DFMS) and dissolved free amino acids (DFAA), as well as oxygen concentrations during first experiment

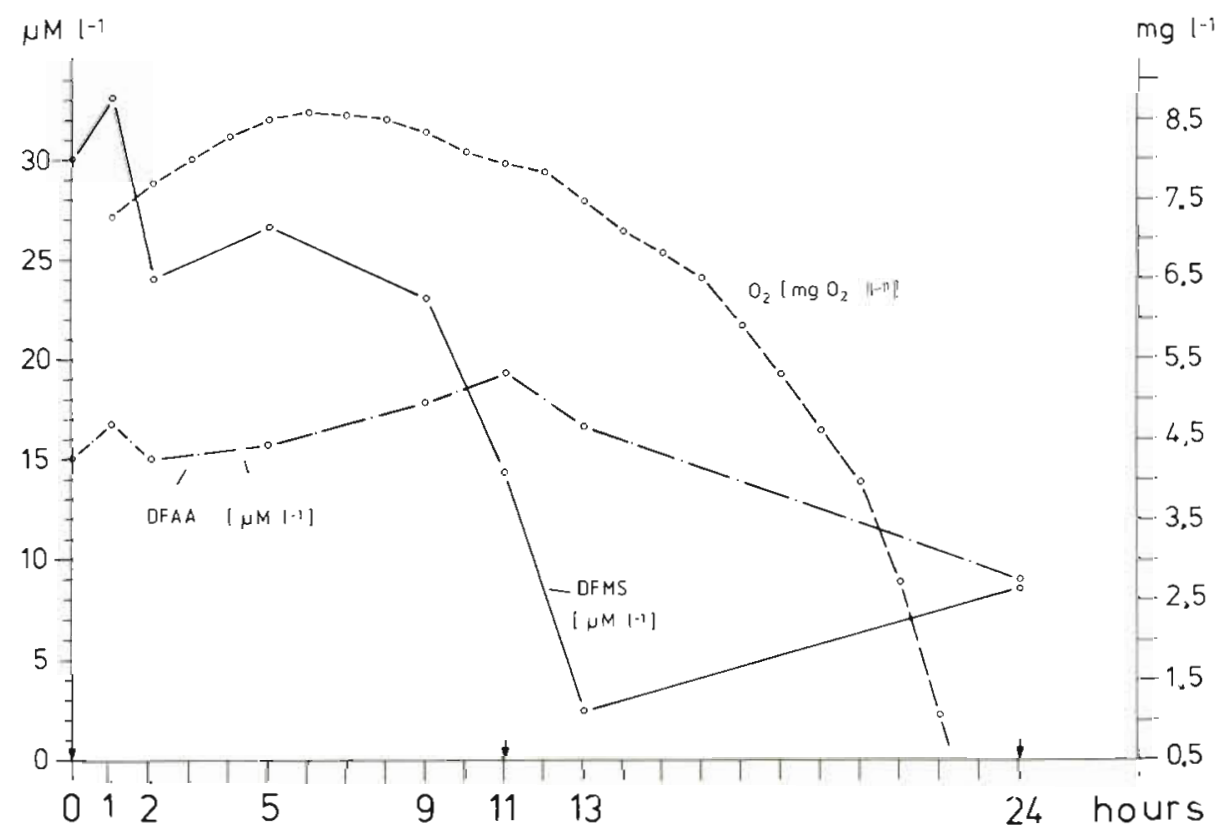


was calculated with factors determined for the Kiel Fjord and Kiel Bight area by Zimmermann (1977). The bacterial biomass was then calculated from these values under the assumption that $10 \%$ of the bacterial volume is equivalent to the bacterial carbon concentration (Schlegel, 1981). For some samples frequency of dividing cells (FDC) was determined according to the suggestions of Hagström et al. (1979) along with the determination of the bacterial numbers. At the same time subsamples were checked for the presence of other small heterotrophic organisms, especially ciliates and flagellates.

Dissolved organic compounds. Subsamples for these determinations were taken from the upper compartment. The dissolved free monosaccharide concentration (DFMS) was determined photometrically according to the method of Johnson and Sieburth (1977). The method was calibrated with a standard solution of glucose. All concentrations are therefore expressed as glucose equivalents. Dissolved free amino acid concentrations (DFAA) were determined with a spectral fluorometer (Jasco FP 550) after addition of fluorescamin (Sigma) according to the method of North (1975). The method was calibrated with a glycin standard. All DFAA concentrations are therefore expressed as glycin equivalents.

Distribution of molecule sizes was determined by adding $2 \mathrm{ml}$ of the unconcentrated water sample from the upper compartment to a gel-chromatography column, filled with Sephadex-G-25 gel (Pharmacia, Sweden). According to the manufacturer's manual, this gel separates molecules in the range of 100 to 5000 daltons. Separation, however, depends not only on size but also on charge and conformation of the molecules. Therefore, only the elution volume and not a distinct molecular weight is indicated. The extinction of the effluent was monitored continuously with a flowthrough photometer (ISCO UA5) at a wavelength of $280 \mathrm{~nm}$.

\section{RESULTS}

The first experiment is discussed in full detail, while results of the other 3 experiments are presented in a more comprehensive way in the form of a table.

For the first experiment water was sampled from the Schlei Fjord near Kappeln. Fig. 2 shows the concentrations of dissolved oxygen, DFMS and DFAA determined in the upper compartment during the $24 \mathrm{~h}$ experiment. While oxygen tension was monitored continuously, the other parameters were determined in subsamples taken $0,1,2,5,9,11,13$, and $24 \mathrm{~h}$ after the start of the experiment. It is obvious from Fig. 2 that the fastest decrease for all 3 parameters occurred during the second half of the incubation. For DFMS concentrations this was observed between 9 and $13 \mathrm{~h}$ after start of the experiment while DFAA were consumed mainly after an incubation period of more than $13 \mathrm{~h}$. There seems to have been a preference for the consumption of sugar compounds.

Fig. 3a to $c$ gives an impression of the distribution of the molecular weight at the beginning (3a), after $11 \mathrm{~h}$ (3b), and at the end of the experiment (3c). On the left side the extinction at $280 \mathrm{~nm}$ is plotted against the elution volume. The first $80 \mathrm{ml}$ of the elution volume were void of organic substances followed by the highmolecular-weight substances, while the smallest molecules were eluted last $(200 \mathrm{ml})$. Fig. $3 \mathrm{a}$ to $\mathrm{c}$ indicates a reduction of the concentration of all molecularsize classes within the first $11 \mathrm{~h}$ of the experiment with little further change towards the end. The most obvious reduction took place in the fraction eluted between 120 and $180 \mathrm{ml}$, which is the fraction of small molecules consisting only of 1 or a few amino acid or sugar compounds. To assess the DFMS and DFAA concentrations in the elution fluid, $5 \mathrm{ml}$ fractions were collected between 120 and $200 \mathrm{ml}$, and these parameters were determined in the subsamples. The results are presented on the right side of Fig. 3a to c. Within the incubation period amino acids are reduced nearly to their detection limit, while monosaccharide concentrations are reduced as well, but to a lesser extent. The residual concentration of monosaccharides might have 2 origins: (1) The method applied determines, besides the easily degradable compounds, other carbohydrates (e.g. sugar-alcohols) which bacteria do not take up fast. (2) These DFMS are fragments of high-molecularweight compounds broken-up by bacterial exoenzymes but not ingested immediately. This question is difficult to solve without the determination of the exoenzymatic activity.

In order to follow the development of the bacterial population during incubation, samples from the lower compartment were taken in the same time intervals as those from the upper one (Fig. 4). An increase of bacterial numbers and biomass occurs only in the second half of the experiment (between 13 and $24 \mathrm{~h}$ ), while the frequency of dividing cells (FDC) increases earlier (after $5 \mathrm{~h}$ of incubation). The bacterial biomass increased by a factor of 100 during incubation while bacterial numbers increased only 20 -fold. These values indicate that the average cell volume at the end of the experiment is higher than at the beginning. Increase of cell volume has also been observed in pure cultures of bacteria. After change or addition of nutrients RNA synthesis increased earlier than DNA synthesis in these experiments. Since the largest fraction of RNA is found in the ribosomes, under these conditions the bacteria show a preference for protein 

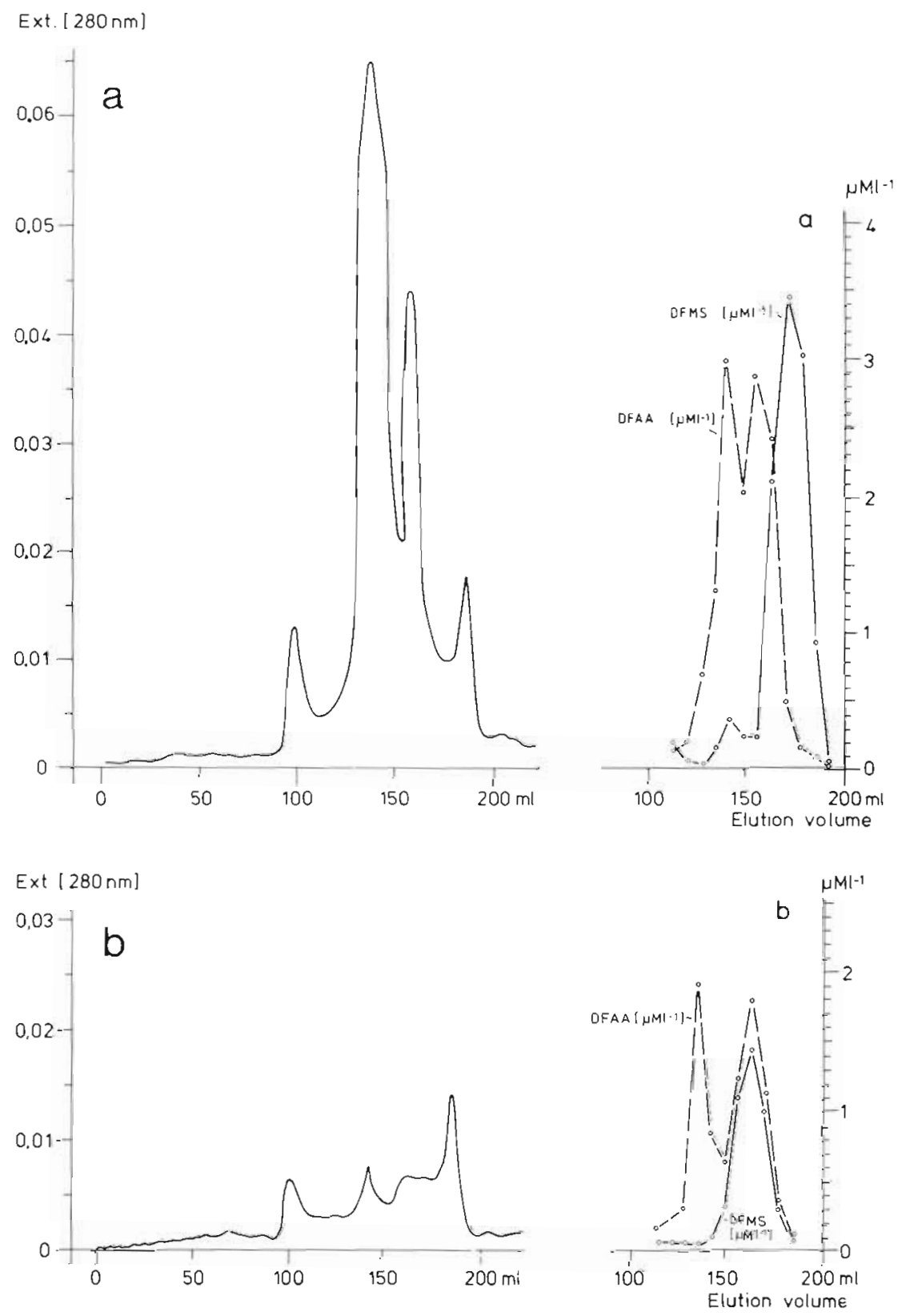

Fig. 3. Separation of dissolved organic compounds according to their molecular size at beginning (3a), middle $(3 b)$, and end (3c) of first experiment. Left side: extinction at $280 \mathrm{~nm}$; right side: concentrations of DFAA and DFMS in fractions of $5 \mathrm{ml}$ between 120 and $180 \mathrm{ml}$ elution volume
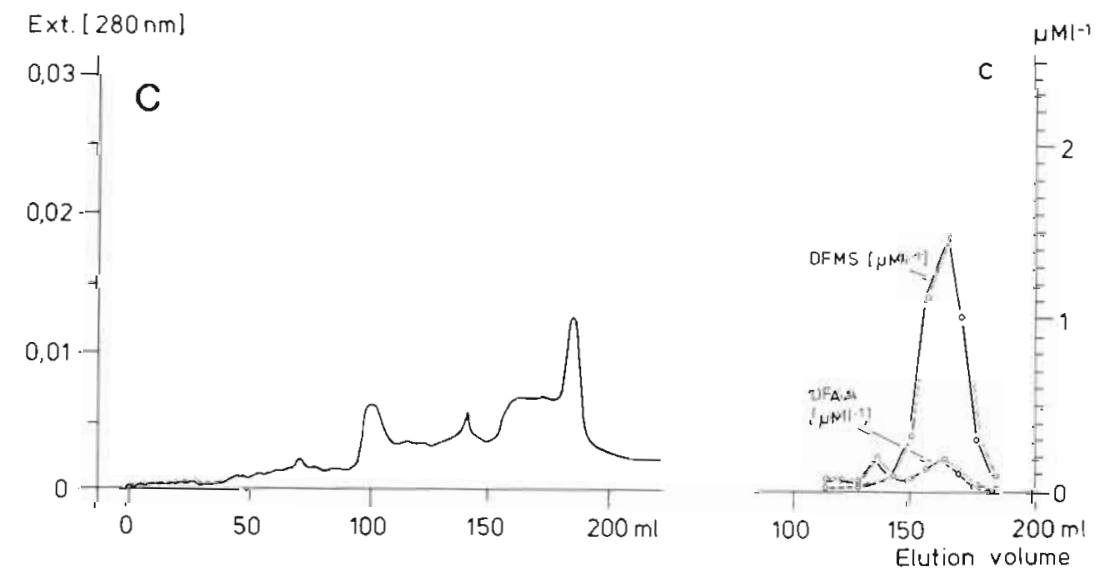


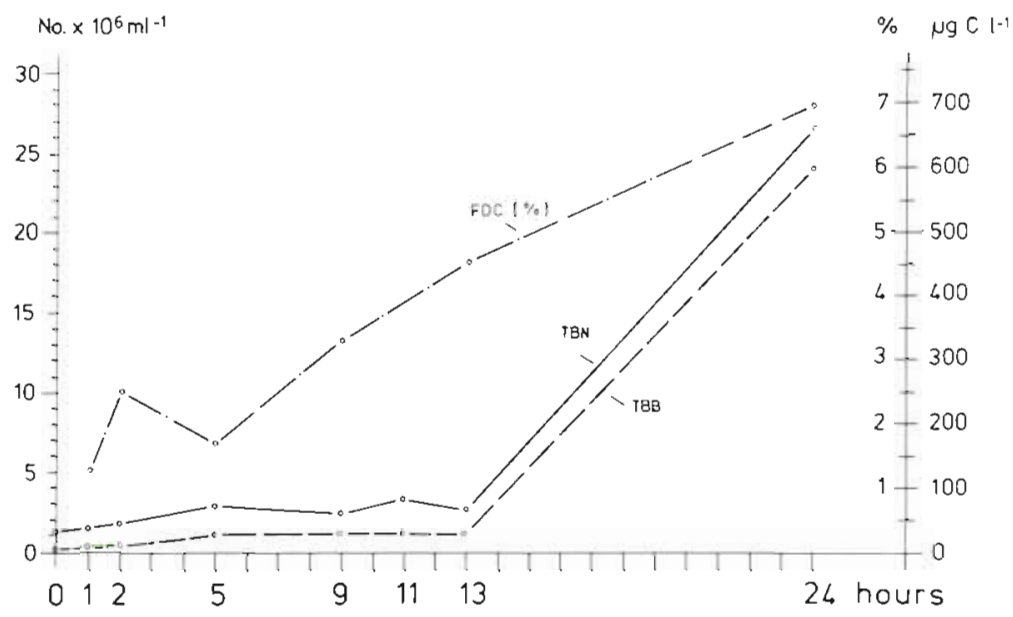

Fig. 4. Total bacterial number (TBN), bacterial biomass (TBB), and frequency of dividing cells (FDC) during first experiment synthesis ( $=$ increase of cell volume) over DNA synthesis (= division) (Brock, 1974). The FDC values calculated for the bacterial population in the experiments described here underestimate the actual growth rate. Therefore, a significant correlation between growth rate, as determined from increase in bacterial biomass, and FDC was not found.

The results of this experiment and those of 3 more experiments are summarized in Table 1 . The third column lists the origin of the water sample and substrate used, while the following columns present concentrations of individual parameters both at the beginning and the end of the experiment. To standardize the results of all experiments, which lasted 22 to $66 \mathrm{~h}, 24 \mathrm{~h}$ values were calculated. The phytoplankton material, characterized only by its release of DFMS and DFAA after heating, is represented by the concentrations of these parameters at the beginning of the experiments. In the first 3 experiments DFMS concentrations are much higher than those of DFAA. This is especially true for the third experiment with Peridinium cells from Lake Kinneret. In experiments following the degradation of dinoflagellates it is quite obvious that these have a high carbohydrate content in relation to their protein content. Parsons et al. (1977) reported a protein content of about $35 \%$, and of $40 \%$ for carbohydrates for dinoflagellates. Wynne et al. (1982) found an even lower protein content of $203 \mu \mathrm{g} \mathrm{mg}^{-1}$ cell dry weight compared with a carbohydrate content of $325 \mu \mathrm{mg}^{-1}$ cell dry weight for $P$. cinctum. For Skeletonema costatum, one of the dominant diatoms of the fourth experiment, a content of $58 \%$ protein and of $33 \%$ carbohydrates was found. DFMS not only show higher concentrations in the first 3 experiments than DFAA, but they are also degraded to a higher extent than the proteinous substances. Possibly, the bacteria do not need the DFAA as a nitrogen source, because there may be enough inorganic nitrogen (ammonia, nitrate) in the water to sustain the nitrogen supply of the bacterial population to some extent. The fourth experiment differs from the other 3, among other things, in that the concentration of the dissolved material was much lower. Therefore, the time of incubation had to be prolonged and the decrease or increase of the parameters was much less.

\section{DISCUSSION}

In the experiments described the decrease of dissolved compounds originating from natural phytoplankton debris was compared with the assimilation of this material by a bacterial population over a relatively short time period. For this purpose carbon assimilation was measured by the increase of bacterial biomass in the absence of predators and by their oxygen consumption, in order to assess the amount of carbon respired or used for metabolic processes. The experimental design had the advantage that addition of labelled substrate was not necessary, thus avoiding all the problems connected with such methods.

In order to estimate carbon flow in the bacterial part of the food chain, decreases in the combined dissolved organic compounds are compared with bacterial biomass production and respiration (Table 2). For this purpose the oxygen concentrations were converted into carbon mineralization. A respiration quotient of 0.75 was used that had been established for the Baltic Sea by Zsolnay (1975). When the values obtained for the decrease in organic solutes are compared with those for gross uptake (Table 2), it becomes obvious that these low-molecular-weight substances cannot be the only carbon source for the bacterial populations. Therefore, the calculation of the growth yield (biomass production/decrease in substrate) would lead to unrealistically high figures. Most probably, the bacterial split high-molecular-weight substances with the help of exoenzymes, followed by uptake of the frag- 
Table 1. Concentration of parameters determined at begin and end of the 4 experiments, and decrease or increase within $24 \mathrm{~h}$

\begin{tabular}{|c|c|c|c|c|c|c|c|c|}
\hline $\begin{array}{l}\text { No. of } \\
\text { expt. }\end{array}$ & $\begin{array}{l}\text { Duration } \\
\text { (h) }\end{array}$ & $\begin{array}{c}\text { Substrate } \\
\text { water sample }\end{array}$ & & $\begin{array}{c}\text { DFAA } \\
\mu \mathrm{gC} l^{-1}\end{array}$ & $\begin{array}{l}\text { DFMS } \\
\mu g C l^{-1}\end{array}$ & $\begin{array}{l}\text { Tot. bact. } \\
\text { number } \\
\text { X } 10^{9} 1^{-1}\end{array}$ & $\begin{array}{l}\text { Tot. bact. } \\
\text { biomass } \\
\mu g \mathrm{C}^{-1}\end{array}$ & $\begin{array}{c}\mathrm{O}_{2} \\
\mathrm{mg} \mathrm{l^{-1 }}\end{array}$ \\
\hline 1 & 24 & $\begin{array}{l}\text { Ceratium sp. } \\
\text { Schlei Fjord }\end{array}$ & $\begin{array}{l}\text { Start } \\
\text { End } \\
\text { Difference in } 24 \mathrm{~h}\end{array}$ & $\begin{array}{r}1000 \\
530 \\
-470\end{array}$ & $\begin{array}{r}2170 \\
620 \\
-1550\end{array}$ & $\begin{array}{r}1.2 \\
26.5 \\
+25.3\end{array}$ & $\begin{array}{r}5.5 \\
597.3 \\
+592.0\end{array}$ & $\begin{array}{r}7.3 \\
0.5 \\
-6.8\end{array}$ \\
\hline 2 & 27 & $\begin{array}{l}\text { Ceratium sp. } \\
\text { Kiel Fjord }\end{array}$ & $\begin{array}{l}\text { Start } \\
\text { End } \\
\text { Difference in } 24 \mathrm{~h}\end{array}$ & $\begin{array}{r}423 \\
352 \\
-71\end{array}$ & $\begin{array}{r}1126 \\
422 \\
-626\end{array}$ & $\begin{array}{r}1.8 \\
21.9 \\
+17.9\end{array}$ & $\begin{array}{r}11.8 \\
554.8 \\
+483.0\end{array}$ & $\begin{array}{r}7.2 \\
1.5 \\
-5.1\end{array}$ \\
\hline 3 & 22 & $\begin{array}{l}\text { Peridinium sp. } \\
\text { Kiel Fjord }\end{array}$ & $\begin{array}{l}\text { Start } \\
\text { End } \\
\text { Difference in } 24 \mathrm{~h}\end{array}$ & $\begin{array}{r}134 \\
82 \\
-57\end{array}$ & $\begin{array}{r}740 \\
91 \\
-708\end{array}$ & $\begin{array}{r}0.5 \\
50.0 \\
+54.0\end{array}$ & $\begin{array}{r}19.6 \\
620.0 \\
+655.0\end{array}$ & $\begin{array}{r}8.4 \\
2.7 \\
-6.2\end{array}$ \\
\hline 4 & 66 & $\begin{array}{l}\text { Diatoms } \\
\text { Central Baltic }\end{array}$ & $\begin{array}{l}\text { Start } \\
\text { End } \\
\text { Difference in } 24 \mathrm{~h}\end{array}$ & $\begin{array}{r}46.8 \\
28.8 \\
-6.5\end{array}$ & $\begin{array}{l}22.8 \\
- \\
-\end{array}$ & $\begin{array}{r}1.8 \\
6.5 \\
+1.7\end{array}$ & $\begin{array}{r}20.2 \\
49.0 \\
+10.5\end{array}$ & $\begin{array}{r}8.1 \\
7.6 \\
-0.2\end{array}$ \\
\hline
\end{tabular}

Table 2. Decrease in organic matter, biomass increase, and respiration during the 4 experiments. Oxygen consumption was converted into $\mathrm{CO}_{2}$ production with a respiration quotient of 0.75 (Zsolnay, 1975)

\begin{tabular}{|c|c|c|c|c|c|}
\hline $\begin{array}{c}\text { No. of } \\
\text { expt }\end{array}$ & 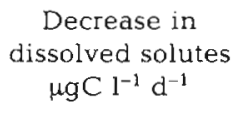 & 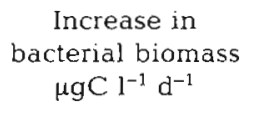 & 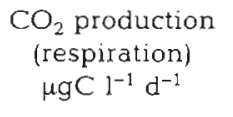 & $\begin{array}{c}\text { gross uptake } \\
\text { (respiration }+ \\
\text { biomass) }\end{array}$ & $\begin{array}{c}\% \text { respiration } \\
\left(\frac{\text { respiration } \times 100}{\text { gross uptake }}\right)\end{array}$ \\
\hline 1 & 2020 & 592 & 2200 & 2792 & 79 \\
\hline 2 & 697 & 483 & 1425 & 1908 & 75 \\
\hline 3 & 765 & 655 & 1749 & 2404 & 73 \\
\hline 4 & - & 10.5 & 51 & 61.5 & 83 \\
\hline
\end{tabular}

ments (Fig. 3). The organic material of all molecular size classes was reduced during incubation.

The amount of carbon originating from the high. molecular-weight substances was not determined along with the DFMS and DFAA concentrations, since the volume of the subsamples was limited. Also, determination of exoenzymatic activity would have been very helpful to quantify this process.

Bacteria use the assimilated carbon in 3 different ways: biomass production, respiration and exudation. The first 2 parameters have been determined for a natural substrate in the experiments described above; however, little is known about the third parameter.

Bacteria do not excrete faeces like other secondary producers (e.g. zooplankton) but release organic material, for example exoenzymes or toxins. This is well known especially for bacteria pathogenic to man. Up to now it has been difficult to quantify the amount of carbon released by bacteria. Sorokin (1978) gives a value of $15 \%$ of their biomass. The amount of exoenzyme production by bacteria depends very much on the substrate they find in their environment: If there are very complex substrates, a high rate of exoenzymes exudation is induced and less carbon is available for biomass production.

Since they have simple ways of reproduction, 'growth' of bacteria is easier to follow than that of other consumers. Most of the bacteria simply divide into 2 daughter cells of the same size. In all 4 experiments, the bacterial biomass increased faster than the bacterial numbers, thus indicating growth of individual cells before division. This phenomenon has been noticed by several authors, when natural population had been nutrient enriched in flasks. It has also been suspected that this might be an artifact. But Rheinheimer (1981) stated an increase of biomass per cell in eutrophication gradients. Also Meyer-Reil (1983) has shown in sediments that, in the absence of predators during winter, there was an increase in cell volume after nutrient input during the fall bloom. In the experiments described here this is probably due to addition of phytoplankton material.

Increase in bacterial biomass adds up to $655 \mu \mathrm{g} \mathrm{Cl}^{-1}$ $\mathrm{d}^{-1}$ for Peridinium cells from Lake Kinneret, and to 500 or $600 \mu \mathrm{g} \mathrm{Cl}^{-1} \mathrm{~d}^{-1}$ for dinoflagellates from the Baltic Sea. These are very high production values, compared 
to bacterial production estimates for the water column. The values show that bacteria are able to react very quickly to the addition of a natural substrate, as might occur in the natural environment, e.g. during sudden breakdown of a phytoplankton bloom. Production values on the same order of magnitude were found by Meyer-Reil (1983) in sediments of the Kiel Bight after input from the autumn phytoplankton bloom, and in spring at low temperatures in the absence of predators (9 to $16 \mu \mathrm{g} \mathrm{C} \mathrm{g}{ }^{-1}$ sediment $\mathrm{d}^{-1}$ ). These values were determined from the increase in bacterial biomass within $2 \mathrm{wk}$, but corresponded well with production values established by other authors using thymidineuptake measurements (Meyer-Reil, 1983). High production rates in the water column, however, might not occur due to the presence of bacterial grazers, excluded in our experiments.

An important question about the role of bacteria in the aquatic ecosystem concerns the amount of respiration: Do bacteria pass most of the carbon assimilated up the food chain or is most of it respired and therefore lost to the consumption by secondary consumers?

Percentage of respiration has been determined mostly for single substrates, labelled with radioactive carbon, by trapping the evolving $\mathrm{CO}_{2}$. This method, first published by Hobbie and Crawford (1969), has been used on water samples in the Kiel Fjord and Kiel Bight area by several authors. Respiration rates mostly below $40 \%$ were determined (Gocke, 1976; MeyerReil et al., 1978; Saltzmann, 1980; Bölter, 1981; Bauerfeind, 1982). The resulting high growth efficiencies (mostly above $60 \%$ ) stressed the importance of bacteria as 'food' for secondary consumers. Some authors (e.g. Hanson and Wiebe, 1977; Billen et al., 1980) have pointed out that the ${ }^{14} \mathrm{CO}_{2}$ respired during the shortterm incubation might be non-proportional to the ${ }^{12} \mathrm{CO}_{2}$ respired, because shortly after addition of labelled substrate no equilibrium is reached and more ${ }^{12} \mathrm{C}$ than ${ }^{14} \mathrm{C}$ is respired. Therefore the respiration rate calculated from ${ }^{14} \mathrm{CO}_{2}$ values might be underestimated. Billen et al. (1980) recalculated their figures and obtained respiration rates between 50 and $80 \%$ in the Scheldt Estuary for substrates of low molecular weight (e.g. glucose, amino acid mixture). Sepers et al. (1982) also pointed out that remineralization rates obtained with the ${ }^{14} \mathrm{C}$ method were normally less than $10 \%$ of those calculated from oxygen consumption measurements. These differences may be due to the different substrates offered in the experiments. While the uptake measurements are normally done with single low-molecular-weight substances, for oxygen consumption measurements the whole spectrum of organic material contained in the water sample is offered. A complex substrate was offered to the bacteria in the experiments described here and the oxygen consumption was measured directly, thus avoiding all the problems referred to above. Although the organic material was added in quite different quantities, the percentage of respiration (Table 2) is quite similar for all experiments and ranges between 70 and $80 \%$. These are high respiration rates, compared to the data obtained with single low-molecular-weight substrates. But as mentioned above, the complex substrates in these experiments must be broken down partly by exoenzymes prior to their uptake. For these metabolic processes more energy is needed than for small molecules.

Our results indicate that, although bacterial biomass production is quite high, it represents only 20 to $30 \%$ of the total carbon assimilated. The percent respiration rates in all 4 experiments are very similar, although the concentrations of the bacterial carbon and dissolved substrates are much lower in the last experiment than in the first three.

\section{CONCLUSIONS}

Bacterial growth is stimulated during degradation periods of phytoplankton (Fuhrman et al., 1980). Phytoplankton bloom in the Kiel Bight area sediment to a lesser extent in summer and fall than in spring, due to grazing of zooplankton. Experiments by Hertzig et al. (1981) with Peridinium cells in Lake Kinneret also indicate a high degradation loss in the euphotic zone of the lake. In both cases, dissolved organic material was made available for the bacterial population due to cell lysis and 'sloppy feeding' of zooplankters. This process has been simulated in our experiments. Consumption and respiration rates were determined without addition of a labelled substrate. Algal detritus added to the natural bacterial population stimulated its activity. Bacteria took up the dissolved organic substances very rapidly. There seemed to be no preference for the low-molecular-weight compounds (DFAA and DFMS), if a 24 h period of incubation was considered. In experiments with detritus of dinoflagellates, bacteria took up DFMS faster than DFAA, but the residual concentration was higher for DFMS than for DFAA.

Maximal increase in bacterial biomass was $650 \mu \mathrm{g}$ $\mathrm{Cl}^{-1} \mathrm{~d}^{-1}$. These production values are much higher than those reported in the literature for pelagic bacteria (van Es and Meyer-Reil, 1982; Newell and Linley, 1984), but they are on the same order of magnitude as in the sediment (Meyer-Reil, 1983). These high production values indicate, that the bacterial community is able to react very fast, when nutrients are added to its environment. Possibly, this bacterial production has been overlooked in other investigations, because bacterial grazers were not excluded. 
Although the production values are very high, they account only for 20 to $30 \%$ of the gross uptake. Direct oxygen measurements indicated that 70 to $80 \%$ of the carbon consumed by bacteria is respired. This emphasizes the important role of bacteria for remineralization. Such high respiration rates were found as well in the degradation experiment with diatoms, although the concentrations of all parameters studied were much lower than in the other experiments. This shows that the high respiration rates are not only due to high concentrations of organic material. All our results indicate that bacteria already assume an important role in the breakdown of phytoplankton carbon during the process of sedimentation.

Acknowledgements. This study was part of the author's dissertation at the University of Kiel, supported by the Federal Ministry for Research and Technology, Bonn, FRG, Project MFU 0506/9. I thank K. Bach for the construction of the oxygen chamber and Professor T. Berman, Tiberias (Israel) for providing me with freeze-dried Peridinium cells. I am grateful to Professor Dr. G. Rheinheimer, Dr. L.-A. Meyer-Reil and Dr. K. Wolter for critical reviews of my manuscript. Gratitude is further expressed to Miss Petra Stegmann for correcting the English manuscript and to Mrs. S. Jasper-Morvan for typing it.

\section{LITERATURE CITED}

Bauerfeind, S. (1982). Versuche zum Abbau von Plankton und Detritusmaterial durch natürliche Bakterienpopulation der Schlei und der Ostsee. Dissertation, Universität Kiel

Billen, G., Joiris, C., Wijnant, J., Gillian, G. (1980). Concentration and microbiological utilization of small organic molecules in the Scheldt Estuary, the Belgian coastal zone of the North Sea and the English Channel. Estuar. coast. mar. Sci. 11: 279-294

Bölter, M. (1981). DOC-turnover and microbial biomass production. Kieler Meeresforsch. Sonderh. 5: 304-310

Brock, T. D. (1974). Biology of microorganisms. Prentice Hall, Inc., Englewood Cliffs, New Jersey

Es, van F. B., Meyer-Reil, L.-A. (1982). Biomass and metabolic activity of heterotrophic marine bacteria. Adv. microb. Ecol. 6: 111-170

Fuhrmann, J. A., Ammermann, J. W., Azam, F. (1980). Bacterioplankton in the coastal euphotic zone: distribution, activity and possible relationship with phytoplankton. Mar. Biol. 60: 201-207

Gast, V. (1983). Untersuchungen über die Bedeutung der Bakterien als Nahrungsquelle für das Mikrozooplankton der Schlei und der Ostsee unter besonderer Berücksichtigung der Ciliaten. Dissertation, Universität Kiel

Gocke, K. (1976). Respiration von gelösten organischen Verbindungen durch natürliche Mikroorganismenpopulationen. Ein Vergleich $z$ wischen verschiedenen Biotopen. Mar. Biol. 35: 375-383

Gocke, K. (1977). Heterotrophic activity. In: Rheinheimer, G. (ed.) Microbial ecology of a brackish water environment. Springer Verlag, Berlin, Heidelberg, New York, p. 198-222

Grasshoff, K. (1976). Methods of seawater analysis. Verlag Chemie, Weinheim, New York

Hagström, A., Larsson, U., Hörstedt, P., Nordmark, S. (1979). Frequency of dividing cells, a new approach to the deter- mination of bacterial growth rates in aquatic environments. Appl. environ. Microbiol. 37: 805-812

Hanson, R. B., Wiebe, W. J. (1977). Direct measurements of dissolved organic carbon release by phytoplankton and incorporation by microheterotrophs. Mar. Biol. 42: $321-330$

Hertzig, R., Dubinsky, Z., Berman, T. (1981). Breakdown of Peridinium biomass in Lake Kinneret. In: Shuval, H. J. (ed.) Developments in arid zone ecology and environmental quality. Ballaban International Science Service, Rehavot, Israel, Philadelphia, USA, p. 179-185

Hobbie, J. E., Crawford, C. C. (1969). Bacterial uptake of organic substrate: new methods of study and application to eutrophication. Verh. int. Verein. Limnol. 17: 725-730

Johnson, K. M., Sieburth, J. McN. (1977). Dissolved carbohydrates in seawater, I: a precise spectrophotometric analysis for monosaccharides. Mar. Chem. 5: 1-13

Johnson. K. M., Burney, C. M., Sieburth, J. McN. (1981). Enigmatic marine ecosystem metabolism measured by direct diel $\mathrm{CO}_{2}$ and $\mathrm{O}_{2}$ flux in conjunction with DOC release and uptake. Mar. Biol. 65: 49-60

Larsson, U., Hagström, ̊. (1982). Fractionated phytoplankton primary production, exudate release and bacterial production in a Baltic eutrophication gradient. Mar. Biol. 67: $57-70$

Meyer-Reil, L.-A., Dawson, R., Liebezeit, G., Tietge, H. (1978). Fluctuations and interactions of bacterial activity in sandy beach sediments and overlying waters. Mar. Biol. 48: 161-171

Meyer-Reil, L.-A. (1983). Benthic response to sedimentation events during autumn to spring at a shallow water station in the Western Kiel Bight. II. Analysis of benthic bacterial populations. Mar. Biol. 77: 247-256

Newell, R. C., Lucas, M. I., Linley, E. A. S. (1981). Rate of degradation and efficiency of conversion of phytoplankton debris by marine microorganisms. Mar. Ecol. Prog. Ser. 6: 123-136

Newell, R. C., Linley, E. A. S. (1984). Significance of microheterotrophs in the decomposition of phytoplankton: estimates of carbon and nitrogen flow based on the biomass of plankton communities. Mar. Ecol. Prog. Ser. 16: 105-119

North, B. B. (1975). Primary amines in California coastal waters: utilization by phytoplankton. Limnol. Oceanogr. 20: 20-27.

Parsons, T. R., Takahashi, M., Hargrave, B. (1977). Biological oceanographic processes, 2nd ed. Pergamon Press, Oxford

Rheinheimer, G. (1981). Mikrobiologie der Gewässer, 3. Auflage. Gustav Fischer Verlag, Jena

Saltzmann, H. A. (1980). Untersuchungen über die Veränderungen der Mikroflora beim Durchgang von Brackwasser durch die Kühlanlagen von Kraftwerken. Dissertation, Universität Kiel

Schlegel, H. G. (1981). Allgemeine Mikrobiologie, 5. Auflage. Thieme Verlag, Stuttgart, New York

Sepers, A. B. J., Cahet, G., Goossens, H. (1982). Comparison between the carbon-14 and oxygen consumption method for the determination of the activity of heterotrophic bacterial populations. Mar. Biol. 66: 237-242

Smetacek, V. (1978). Die Jahressukzession des Phytoplanktons: Ursache und Bedeutung für das marine Okosystem. Verh. Ges. Okol., Kiel 1977: 23-28

Sorokin, Y. I. (1978). Decomposition of organic matter and nutrient regeneration. In: Kinne, O. (ed.) Marine ecology, Vol. IV, Dynamics. Wiley and Sons, Chichester, p. 501-616

Wolter, K. (1980). Untersuchungen zur Exsudation 
organischer Substanz und deren Aufnahme durch natürliche Bakterienpopulationen. Dissertation, Universität Kiel

Wolter, K. (1982). Bacterial incorporation of organic substances released by natural phytoplankton populations. Mar. Ecol. Prog. Ser. 7: 287-295

Wright, R. T., Hobbie, J. E. (1966). Use of glucose and acetate by bacteria and algae in aquatic ecosystems. Ecology 47 : $447-464$

Wynne, D., Patni, N. J., Aaronson, S., Berman, T (1982). The relationship between nutrient status and chemical composition of Peridinium cinctum during the bloom in Lake Kinneret. J. Plankton Res. 4: 125-136
Zimmermann, R. (1977). Estimation of bacterial number and biomass by epifluorescence microscopy and scanning electron microscopy. In: Rheinheimer, G. (ed.) Microbial ecology of a brackish water environment. Springer Verlag, Berlin, Heidelberg, New York, p. 103-120

Zimmermann, R., Iturriaga, R., Becker-Birck, J. (1978). Simultaneous determination of the total number of aquatic bacteria and the number thereof involved in respiration. Appl. environ. Microbiol. 36: 926-935

Zsolnay, A. (1975). Total labile carbon in the euphotic zone of the Baltic Sea as measured by BOD. Mar. Biol. 29: 125-128

This paper was submitted to the editor; it was accepted for printing on September 29, 1984 